\title{
Review of Narratives of Adult English Learners and Teachers: Practical Applications
}

\author{
Susan Finn Miller, Lancaster Lebanon IU13 Community Education
}

Both current adult English as a Second Language (ESL) practitioners and those who aspire to work in the field of adult ESL will benefit from reading Clarena Larrotta's book. The book summarizes interviews and observations of adult learners and ESL instructors in central Texas as well as graduate students preparing to become teachers. Through case studies, Clarena Larrotta honors the voices and experiences of adult English learners and their teachers. Drawing from the narratives featured in these case studies, the author underscores effective instructional practices. She also offers words of critique to highlight some of the challenges she sees and to offer suggestions for supporting immigrants who are seeking to learn English.

Larrotta's qualitative research is framed around the concept of "engaged scholarship" which seeks to support a meaningful, collaborative, and reciprocal relationship between the university and the community for the benefit of all those involved. This work seeks to emulate, validate, and promote Barkhuizen's $(2007,2014)$ narrative approach to research and teaching practice which engages teachers and learners in reflecting upon their personal stories as a means to deepen the learning of the adult students and their instructors as well as the researcher. These stories will resonate with practitioners working in the field of adult ESL.

Larrotta appreciates the importance of second language acquisition theory and emphasizes the value of a learner-centered pedagogy based on the principles of Paolo Freire. Her approach begins with the assumption that every adult learner has prior knowledge, strengths, and talents, i.e., "funds of knowledge," that should be drawn upon for learning. In addition, she explains that language instruction should engage learners in meaningful, authentic language experiences. 
Dialogue between learner and teacher are at the heart of the matter for the purpose of discovering what is important to learners. The stories from adult learners and teachers illustrate how building on learners' strengths supports them to achieve their personal goals.

The chapters in the first section of the book highlight learners' voices related to reading, transitioning from oral language to print, building confidence through family literacy, and exploring adult learner motivations. The chapters in the second section feature the voices of practitioners who teach in religious organizations as well as libraries. There is also a chapter in this section devoted to training teachers as well as one on negotiating an adult ESL curriculum in collaboration with adult learners.

Each chapter is organized in a similar fashion by first offering a word of explanation related to the content, followed by the stories of adult learners and teachers in their own voices. Larrotta adds valuable commentary to the narratives by expanding on theoretical principles as well as by offering concrete suggestions for programs serving immigrants. At the end of each chapter, readers will find specific recommendations for practice and a set of questions for discussion.

There are not many books that describe the world of adult ESL; for that reason alone, this book is a welcome contribution. Larrotta's text pays respect to the teachers, graduate students, and adult learners featured in the book and describes their context in some detail. In portraying the various settings, the author does so with candor, which acknowledges the challenges adult literacy practitioners often face including limited instructional resources and training opportunities available to teachers and volunteers.

While the book is certainly valuable overall, there are some minor issues that could be improved. The authorial voice in a few places in the text is unclear. Larrotta usually uses third person to refer to herself; however, there are also some firstperson references that create a bit of confusion. For instance, it is unclear whether Larrotta is the teacher described in chapter 2 who worked with Alberto while he was reading the novel, The Kingdom of the Golden Dragon, by Isabel Allende. Later, in chapter 3 when describing an after-school literacy class, the author states, "I was the instructor ...," but on the same page refers to "the instructor" in the third person.

The book weaves together practice and theory in a compelling way; however, the transitions between the two could, at times, be improved. In a few places, the lack of an appropriate transition makes the text somewhat unclear. In addition, while not essential to the overall value of this resource, the photos featured are of poor quality.

Putting the minor weaknesses aside, those serving adult English learners as well as anyone who wants to better understand the field of adult ESL will learn much from reading this book. By placing the voices of teachers and learners at the center, the text leaves the reader with a complex mosaic of the field as it exists today. The solid theoretical underpinnings of Larrotta's words, the concomitant examples of actual programming, and the author's concrete recommendations for ways to enhance the work being done make this text a worthwhile read. 


\section{References}

Barkhuizen, G. (2007). A narrative approach to exploring context in language teaching. ELT Journal 62(3), 231-239.
Barkhuizen, G. (2014). Narrative research in language teaching and learning. Language Teaching 47(4), 450-466. 